УДК $595.783: 632.78$

Швиденко I. M. https://orcid.org/0000-0003-4383-7604

Кардаш Є. C. https://orcid.org/0000-0002-1555-7958

Колєнкіна М.C. https://orcid.org/0000-0002-5612-0947

\title{
ОСОБЛИВОСТІ ДИНАМІКИ ЩІЛЬНОСТІ МІН І ФЕНОЛОГІЇ KAIITAHOBOГО MIHEPA (CAMERARIA OHRIDELLA DESCHKA \& DIMIC, 1986) У ЗЕЛЕНИХ НАСАДЖЕННЯХ М. ХАРКІВ
}

\author{
(C) Швиденко I.M. ${ }^{1}$, Кардаш Є.C. ${ }^{2}$, Колєнкіна M.C. ${ }^{3}$ \\ ${ }^{1}$ Харківський національний аграрний університет ім. В.В. Докучаєва \\ i.shvydenko.mikulina@gmail.com \\ ${ }^{2}$ Харківський національний педагогічний університет імені Г. С. Сковороди \\ atamansha019@gmail.com \\ ${ }^{3}$ Харківський наиіональний університет міського господарства ім. О.М. Бекетова \\ kolenkinamarina@gmail.com \\ https://doi.org/10.34142/2708-5848.2020.22.2.07
}

\begin{abstract}
Метою досліджень є оцінювання особливостей багаторічної та сезонної динаміки щільності мін і фенології каштанового мінера Cameraria ohridella Deschka \& Dimic, 1986 (Lepidoptera, Gracillariidae) у різних типах зелених насаджень м. Харків у період 2017-2020 рр. та зіставлення цих результатів із даними 2008-2011 рр. на тлі відповідних показників перебігу температури повітря. Встановлено, що у перші роки інвазії (2008-2011 рр.) в зелені насадження м. Харків щільність мін каштанового мінера мала тенденцію до збільшення, а у парках була значно більшою, ніж у вуличних насадженнях. У 2017-2020 р. значення цього показника є близькими в усіх типах насаджень, за винятком молодих дерев у перші роки після садіння. Виліт метеликів каштанового мінера навесні відбувається після стійкого переходу температури через 10 , але до ії переходу через $15^{\circ} \mathrm{C}$. У порівнянні з $2008-$ 2011 рр. вегетаційний період у 2017-2020 рр. починався раніше, середня температура на дату вильоту метеликів каштанового мінера зросла, а суми додатних, активних і ефективних температур зменшилися. Протягом вегетаційного періоду у зелених насадженнях м. Харків розвиваються три покоління каштанового мінера, причому період найбільшої щільності мін у другій декаді липня виражений найчіткіше. Щільність мін в окремі дати розвитку весняного покоління залежить від мікроклімату в місцях знаходження лялечок в опалому листі, перебігу температури в період відкладання метеликами яєць і розвитку личинок і лялечок. На щільність мін у другу половину літа впливає перекривання термінів розвитку окремих поколінь і поступовий ухід у діапаузу частини популяції. Останніх лялечок каштанового мінера виявляли у кронах на декілька днів раніше від дати стійкого переходу температури повітря вниз через $15^{\circ} \mathrm{C}$, а листя опадало у терміни, дуже близькі до дати стійкого переходу температури повітря вниз через $10^{\circ} \mathrm{C}$. Зазначені явища у 2017-2020 рр. зареєстровані пізніше, ніж у 2008-2012 pp., а суми додатних, активних і ефективних температур на дату початку опадання листя гіркокаштана звичайного у 2017-2020 pр. є більшими, ніж у 2008-2012 рр. Розраховано, що у зелених насадженнях м. Харків каштановий мінер «гарантовано» розвивається у трьох поколіннях на рік. Водночас зважаючи на зміни дат початку й завершення сезонного розвитку каштанового мінера, можна очікувати, що певна частка популяції буде розвиватися в додатковому поколінні.
\end{abstract}

Ключові слова: Cameraria ohridella, щільність мін, сезонний розвиток, генерації, температура повітря, сума температур.

Каштанового мінера (Lepidoptera: Gracillariidae, Cameraria ohridella Deschka \& Dimic, 1986) виявлено поблизу Охридського озера в лісах Македонії в 1984-1985 рр., що спричинило його латинську назву "охридський мінер" [4]. У регіоні першого виявлення каштановий мінер не завдавав помітної шкоди гіркокаштану звичайному (Aesculus hippocastanum L.), який росте у природних лісах. Водночас вже у 1996 році каштанового мінера виявлено у Центральній Європі [7, 19], у 1996-1997 pp. - на Заході України, у 2003 році - у Києві [8], у 20062007 - у Харківській області $[6,9,11]$. Нині каштановий мінер завдає шкоду зеленим насадженням гіркокаштана звичайного у більшій частині Європи [7], повсюдно в Україні [3, 8, 12], Білорусі [16], Придністров'ї [4], значною мірою - в Свропейській частині Росії [1] та Казахстані [5]. У міських насадженнях різних регіонів оцінювали щільність мін каштанового мінера, кількість поколінь, вплив на приріст деревини та формування плодів $[2-4,8,14]$. Для запобігання поширенню та прояву шкідливості каштанового мінера запропоновано численні заходи, 
зокрема використання стійких видів роду Aesculus $[14,15]$, знищення лялечок під час зимівлі $[4,7]$, застосування інсектицидів [3, $7,14,18]$.

Дослідження каштанового мінера $\epsilon$ актуальними не тільки 3 погляду запобігання його поширенню, але й для 3'ясування термінів розвитку окремих поколінь та їхньої кількості в умовах глобального збільшення температури [17, 20], а також - особливостей просторово-

\section{МАТЕРІАЛИ І МЕТОДИ}

Дослідження проведені у 2017-2020 pp. у вуличних посадках Шевченківського району м. Харків (5002' пн.ш., 36º $13^{\prime}$ сх.д.), двох парках м. Харків - зокрема парку ім. Т. Шевченка $\left(50^{\circ} 00^{\prime}\right.$ пн.ш., $36^{\circ} 14^{\prime}$ сх.д.) та ім. М. Горького $\left(50^{\circ} 01^{\prime}\right.$ пн.ш., $36^{\circ} 14^{\prime}$ сх.д.), а також - у двох парках Харківського національного аграрного університету ім. В.В. Докучаєва (ХНАУ) (Харківський район Харківської області) - у Парку Ветеранів (49 $89^{\prime}$ пн.ш., $36^{\circ} 45^{\prime}$ сх.д.) й Дендропарку (495' пн.ш., $36^{\circ} 27^{\prime}$ сх.д.).

Усі дерева гіркокашатана звичайного, обстежені в зазначених пунктах обліку, мали діаметр понад $30 \mathrm{~cm}$ і вік понад 50 років, та з 2007 року щорічно пошкоджувалися каштановим мінером. У зв'язку із цим у 2017-2020 pp. ми проводили облік щільності мін цієї комахи додатково на деревах гіркокашатана, висаджених у ЦПКіВ ім. Горького у 20172019 pp.

Дерева гіркокаштана обстежували за загальноприйнятими методами [11]. Раз на тиждень від початку розвитку листя до його опадання (травень-вересень) на кожному обліковому пункті зривали по 100 складних листків гіркокаштана, вибраних рандомізовано 3 різних дерев i частин крон, i вміщували в окремі пакети з ярликами. Під час камеральної обробки матеріалу визначали кількість мін, гусениць, лялечок та екзувіїв каштанового мінера на кожному листку.

Дані стосовно щільності мін каштанового мінера у 2017-2020 pp. зіставлено 3 даними, одержаними у 2008-2011 pр. в тих самих насадженнях [14]. Дані згруповані за часової сезонної та багаторічної динаміки популяцій цього виду в різних типах міських насаджень [2, 8, 13].

Метою досліджень є оцінювання особливостей багаторічної та сезонної динаміки щільності мін і фенології каштанового мінера у різних типах зелених насаджень м. Харків у період 2017-2020 pp. та зіставлення цих результатів із даними 2008-2011 pp. на тлі відповідних показників перебігу температури повітря.

категоріями «парки Харкова», «вулиці» та «парки ХНАУ». До окремої категорії зараховані групи молодих дерев гіркокаштана, висаджених у ЦПКіВ ім. Горького у 2017-2019 pр. («ЦПКіВ, молоді дерева»).

Під час аналізу погодних умов використовували дані метеостанції Харків стосовно щоденної температури повітря та кількості опадів за 2007-2020 pр.

Суми додатних, активних i ефективних температур (при порозі $10^{\circ} \mathrm{C}$ ), a також дати стійкого переходу температури повітря через 5,10 i $15{ }^{\circ} \mathrm{C}$ навесні та восени визначали за методикою В. Л. Мєшкової [10]. Для аналізу зазначених дат, графічного подання та статистичних розрахунків їх виражали як кількість днів від 1 січня (так звані юліанські дати - Julian dates) [10].

Розраховані у 2017-2020 рр. суми додатних, активних i ефективних температур під час проходження окремих етапів розвитку каштанового мінера зіставляли 3 даними, одержаними у 20082012 pp. [13]. Потенційно можливу кількість поколінь каштанового мінера розраховували діленням сум додатних, активних i ефективних температур за період вегетації гіркокашатан на суми відповідних температур, необхідні для розвитку одного покоління цієї комахи.

Розрахунки показників описової статистики та дисперсійний аналіз здійснені за допомогою пакету програм Microsoft Excel. Зокрема розрахунковий критерій Фішера (F) зіставляли 3 його табличним значенням $\left(\mathrm{F}_{0.05}\right)[21]$. 


\section{РЕЗУЛЬТАТИ}

\section{Багаторічна динаміка}

На першому етапі проникнення каштанового мінера у зелені насадження м. Харків середня річна щільність популяції цієї комахи була порівняно невисокою, зокрема у 2008 р. вона становила від 0.3 міни/листок у вуличних посадках до 6.8 міни/листок у парках Харкова (рис. 1).

Упродовж 2008-2010 рр. відбувалося інтенсивне збільшення щільності мін у парках (з максимумами у 2010 році - 49.9 i 39.6 міни/листок у парках Харкова та парках ХНАУ відповідно) i менш інтенсивне - у вуличних посадках, де щільність мін продовжувала наростати протягом усього періоду досліджень. У 2011 році середня річна щільність популяцій каштанового мінера у парках Харкова зменшилася до 31.2 міни/листок, але залишалася достовірно більшою, ніж на інших пунктах обліку ( $\left.\mathrm{F}=21.4 ; \mathrm{F}_{0.05}=4.2\right)$. Водночас щільність популяції каштанового мінера у вуличних посадках, де вона наростала, і у парках ХНАУ, де вона різко зменшилася, у 2011 р. достовірно не відрізнялася $\left(\mathrm{F}=2.5 ; \mathrm{F}_{0.05}=4.3\right)$.

У 2017-2020 p. середня річна щільність мін каштанового мінера була високою на всіх пунктах обліку, за винятком молодих дерев, де вона становила лише 5.2 міни/листок (рис. 1).
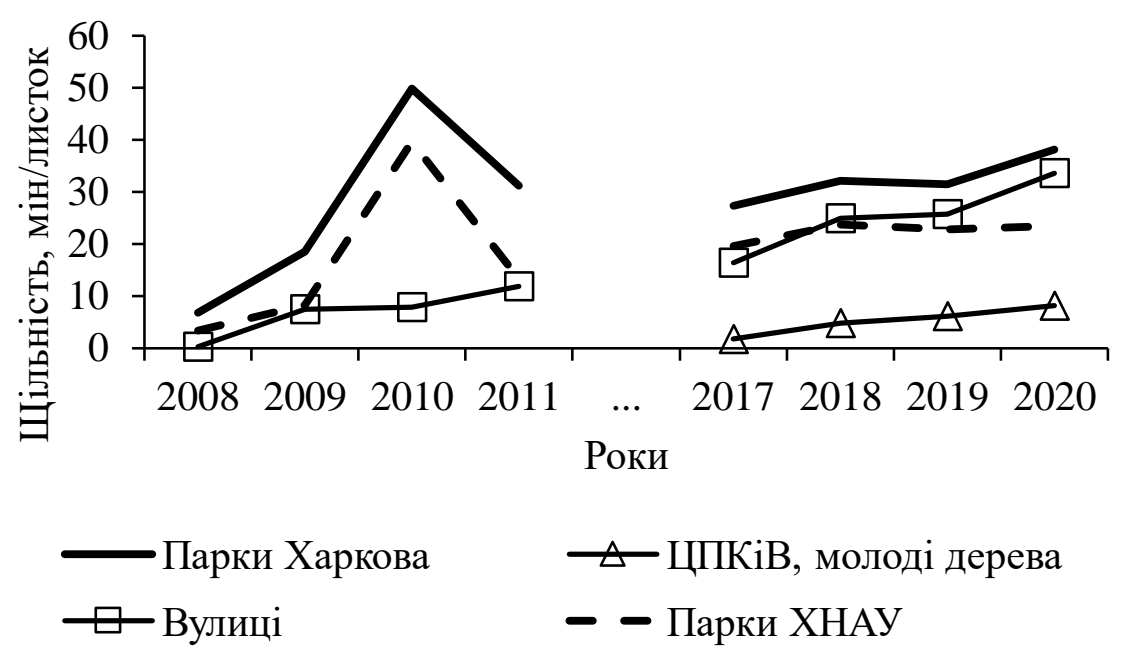

Puc. 1. Багаторічна динаміка середньої річної щільності мін каштанового мінера у зелених насадженнях м. Харків (2008-2011 pр. за даними I.М. Мікуліної [14])

У порівнянні з періодом 2008-2011 pp. середня багаторічна щільність популяцій каштанового мінера у 2017-2020 pp. збільшилася у парках Харкова лише в 1.2 разу (від 26.6 до 32.3 міни/листок), хоча щороку мала найбільші значення серед обстежених насаджень $\left(\mathrm{F}=8.6 ; \mathrm{F}_{0.05}=3.5\right) . \quad \mathrm{У}$ вуличних посадках і парках ХНАУ щільність популяцій каштанового мінера відрізнялася недостовірно ( $\left.\mathrm{F}=1.3 ; \mathrm{F}_{0.05}=4.6\right)$, але у 2017 2020 pp. у порівнянні 3 2008-2011 pp. у вуличних посадках цей показник збільшився у 3.6 разу, а у парках ХНАУ - лише в 1.4 разу. За початковий період інвазії каштанового мінера (2008-2011 рp.) середня річна щільність мін зросла у парках Харкова та у парках ХНАУ у 4.6 і 3.9 разу, а у вуличних посадках - у 39.9 разу. За 2017-2020 рр. темпи збільшення щільності популяції уповільнилися, і за такий самий проміжок часу (4 роки) вона зросла у парках Харкова та парках ХНАУ 1.4 та 1.2 разу відповідно, а на вулицях - удвічі. На молодих деревах, які підсаджували у парки, щільність популяції каштанового мінера за 2017-2020 pр. зросла у 4.6 разу, тобто в такому темпі, в якому показник збільшувався у новому регіоні в перші роки інвазії.

Деякі особливості сезонної динаміки чисельності та фенології

У 2017-2020 рр. перших метеликів каштанового мінера виявлено 
на стовбурах дерев гіркокаштана наприкінці квітня - на початку травня (табл. 1), а перші міни - у 1-2 декадах травня, тобто в період розкриття листя та початку цвітіння цієї породи.

Аналіз даних метеостанції Харків стосовно перебігу температури повітря за
2008-2020 рр. свідчить, що середня дата вильоту метеликів каштанового мінера знаходиться у проміжку часу між стійким переходом температури через 10 i $15{ }^{\circ} \mathrm{C}$ як у роки попередніх досліджень [13], так і у 2017-2020 рр. (табл. 1, рис. 2).

Таблиия 1

Дати вильоту імаго каштанового мінера після зимівлі в зелених насадженнях Харкова та відповідні температурні показники у роки досліджень (2017-2020 рр.) та у 2008-2012 pp.

\begin{tabular}{|c|c|c|c|c|c|c|c|}
\hline \multirow{3}{*}{ Роки } & \multicolumn{3}{|c|}{ Дати } & \multirow{3}{*}{$\mathrm{T}^{\circ} \mathrm{C} *$} & \multirow{2}{*}{\multicolumn{3}{|c|}{ Суми температур, ${ }^{\circ} \mathrm{C}$}} \\
\hline & \multirow{2}{*}{$\begin{array}{c}\text { початку } \\
\text { вильоту } \\
\text { кашта- } \\
\text { нового } \\
\text { мінера }\end{array}$} & \multicolumn{2}{|c|}{$\begin{array}{c}\text { переходу } \\
\text { температури } \\
\text { вверх через }\end{array}$} & & & & \\
\hline & & $10^{\circ} \mathrm{C}$ & $15^{\circ} \mathrm{C}$ & & $\begin{array}{c}\text { додат- } \\
\text { них }\end{array}$ & $\begin{array}{c}\text { актив- } \\
\text { них }\end{array}$ & $\begin{array}{c}\text { ефектив- } \\
\text { них }\end{array}$ \\
\hline 2017 & 5.V & 19.IV & $14 . \mathrm{V}$ & 13.1 & 540.9 & 275.6 & 85.6 \\
\hline 2018 & 25.IV & 11.IV & 26.IV & 15.4 & 308.7 & 225.1 & 55.1 \\
\hline 2019 & 23.IV & 9.IV & 1.V & 15.6 & 394.2 & 179.2 & 39.2 \\
\hline 2020 & $6 . \mathrm{V}$ & 24.IV & $21 . \mathrm{V}$ & 13.4 & 626.9 & 321 & 81.0 \\
\hline \multicolumn{8}{|l|}{ Середні } \\
\hline 2008-2012 & 1. V & 16.IV & $10 . \mathrm{V}$ & 13.7 & 399.5 & 216.4 & 50.4 \\
\hline 2017-2020 & 30.IV & 16.IV & 8.V & 14.4 & 467.7 & 250.2 & 65.2 \\
\hline Різниці & 1 день & 0 & 2 & -0.7 & -68.2 & -33.8 & -14.8 \\
\hline
\end{tabular}

* $\mathrm{T}^{\circ} \mathrm{C}$ - середня температура на дату початку вильоту каштанового мінера

Як свідчать дані табл. 1, у 2017-2020 pp. у порівнянні з даними 2008-2012 pр. середня дата стійкого переходу температури через $10{ }^{\circ} \mathrm{C}$ навесні не змінилася (16.IV), середня дата переходу температури через $15^{\circ} \mathrm{C}$ зареєстрована на два дні раніше, а середня дата вильоту метеликів каштанового мінера - на один день раніше. Середня температура повітря у 2017-2020 pp. у середню дату початку вильоту метеликів $\epsilon$ на $0.7^{\circ} \mathrm{C}$ більшою, ніж у 2008-2012 рр. Водночас середні суми додатних, активних i ефективних температур у середню дату початку вильоту метеликів $\epsilon$ на $68.2,33.8$ та $14.8{ }^{\circ} \mathrm{C}$ меншими у 2017-2020 pp., ніж у 2008-2012 pp.
Упродовж вегетації гіркокаштана виділено три періоди зростання щільності мін каштанового мінера, які відповідають періодам розвитку окремих поколінь цієї комахи (рис. 3). Хоча рівень щільності мін відрізнявся у різних насадженнях, але періоди іiі збільшення та зменшення виявилися дуже подібними. При цьому найбільшу щільність мін визначено у другій декаді липня як у роки наших досліджень 2017-2020 pp., так і під час досліджень 2008-2011 p. [14]. Водночас максимуми першої хвилі («червневої») та третьої («серпневої») виражені нечітко (рис. 3). 


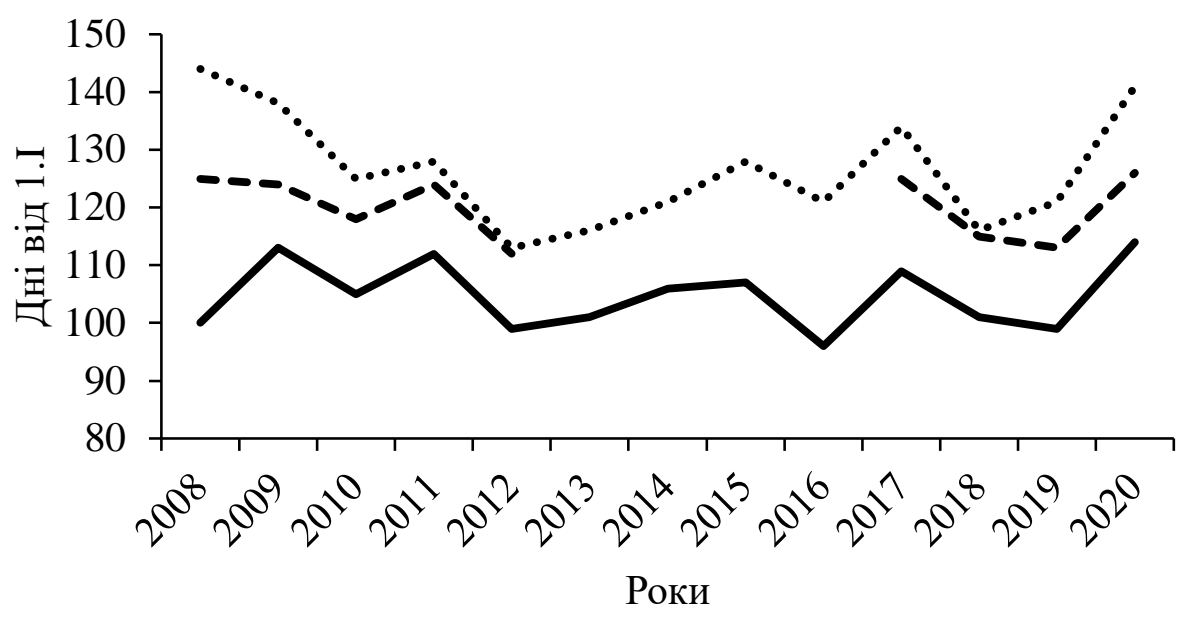

--- Дата вильоту метеликів —Д10 ….. Д15

Puc. 2. Динаміка (2008-2020 рр.) дат стійкого переходу температури повітря навесні через 10 i $15{ }^{\circ} \mathrm{C}$ (Д10 і Д15 відповідно) за даними метеостанції Харків та дат вильоту метеликів каштанового мінера у 2008-2012 рр. за опублікованими даними [13] та у 2017-2020 pp. за власними даними (дати виражені у кількості днів від 1 січня).

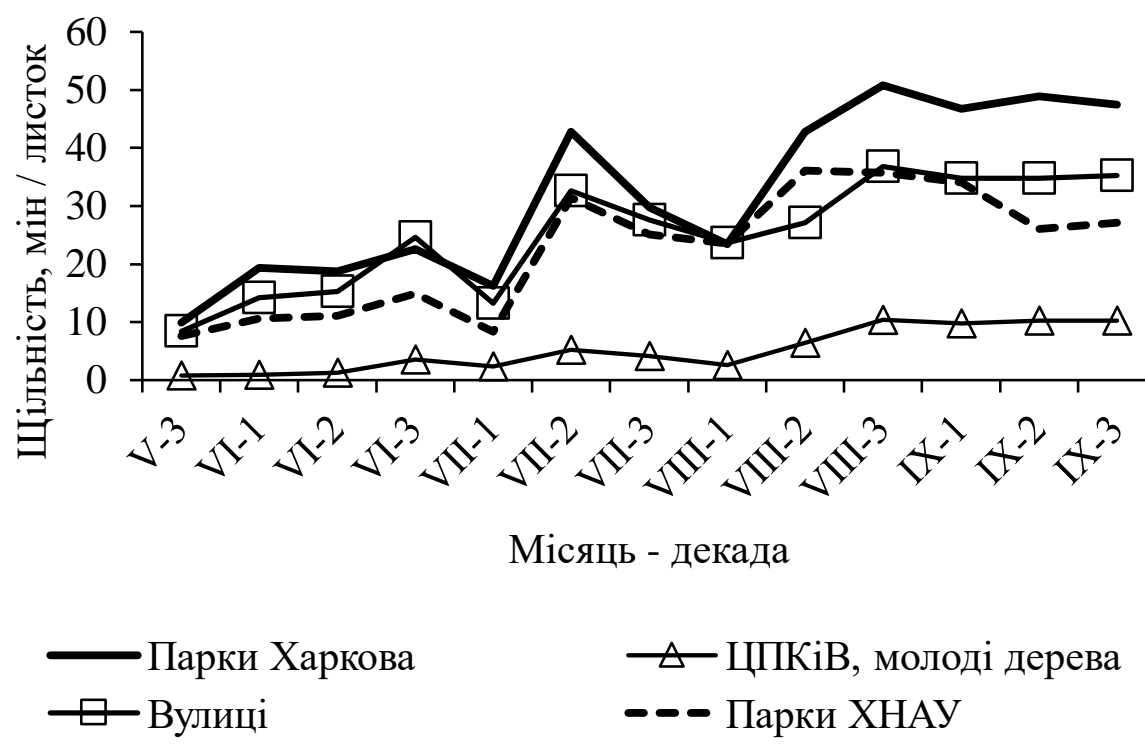

Puc. 3. Сезонна динаміка середньої щільності мін каштанового мінера у зелених насадженнях Харкова (2017-2020 pp.)

Розвиток потомства метеликів каштанового мінера, які розвивалися 3 лялечок, що зимували, відбувався неодночасно в різних пунктах обліку та в різні роки у зв'язку 3 мінливістю мікроклімату. Внаслідок цього лялечок та імаго другого покоління виявляли з третьої декади червня до кінця липня (рис. 4). На цей час на листках гіркокаштана вже живилися гусениці третього покоління, які завершували розвиток у серпні. Водночас на початку вересня більшість лялечок почали йти в діапаузу, а екзувіїв не виявляли, тоді як живлення гусениць тривало, якщо листя не втратило якості.

Зіставлення даних обліків каштанового мінера й термінів опадання листя гіркокаштана у різні роки з осіннім перебігом температури свідчить, що останніх лялечок у кронах виявляли у дати, близькі до стійкого переходу температури повітря нижче $15^{\circ} \mathrm{C}$ (рис. 5). Водночас 
вже у 2012 р. [13] та за нашими даними 2017-2020 рр. останніх лялечок виявляли на декілька днів раніше від дати стійкого переходу температури повітря вниз через $15^{\circ} \mathrm{C}$.
Опадання листя гіркокаштана відбувалося у терміни, дуже близькі до дати стійкого переходу температури повітря через $10{ }^{\circ} \mathrm{C}$ (рис. 5).

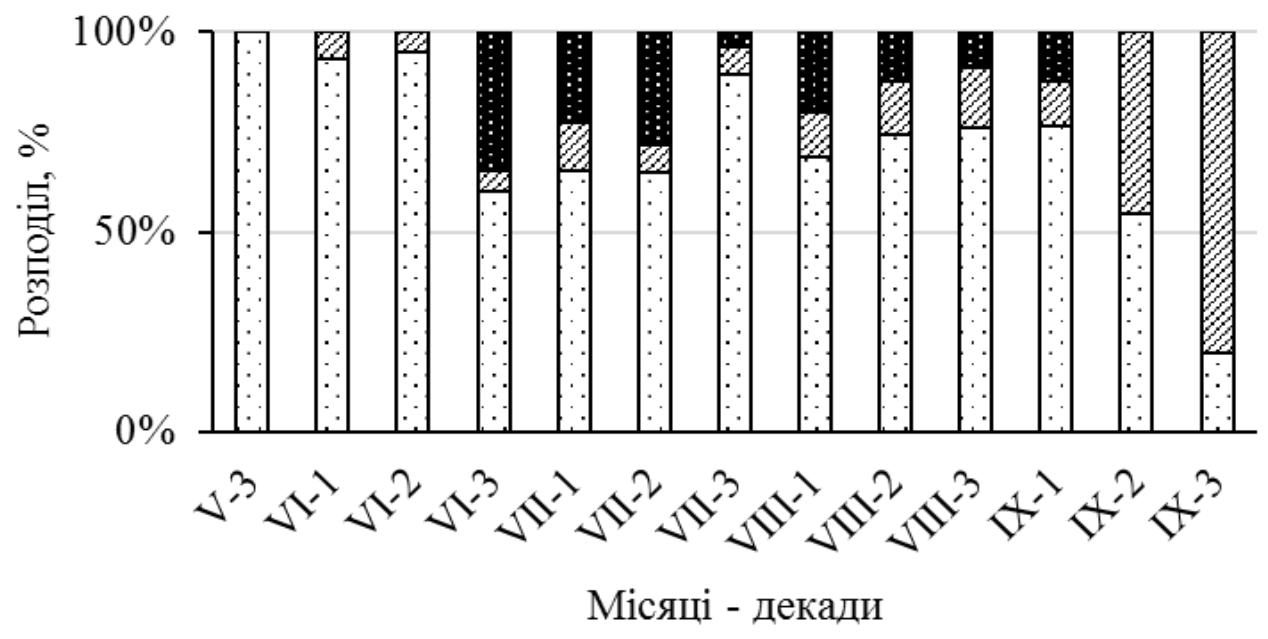

๑Гусениці ఐЛялечки ВЕкзувії

Puc. 4. Динаміка співвідношення гусениць, лялечок і екзувіїв каштанового мінера протягом вегетаційного періоду (середнє за 2017-2020 рр.)
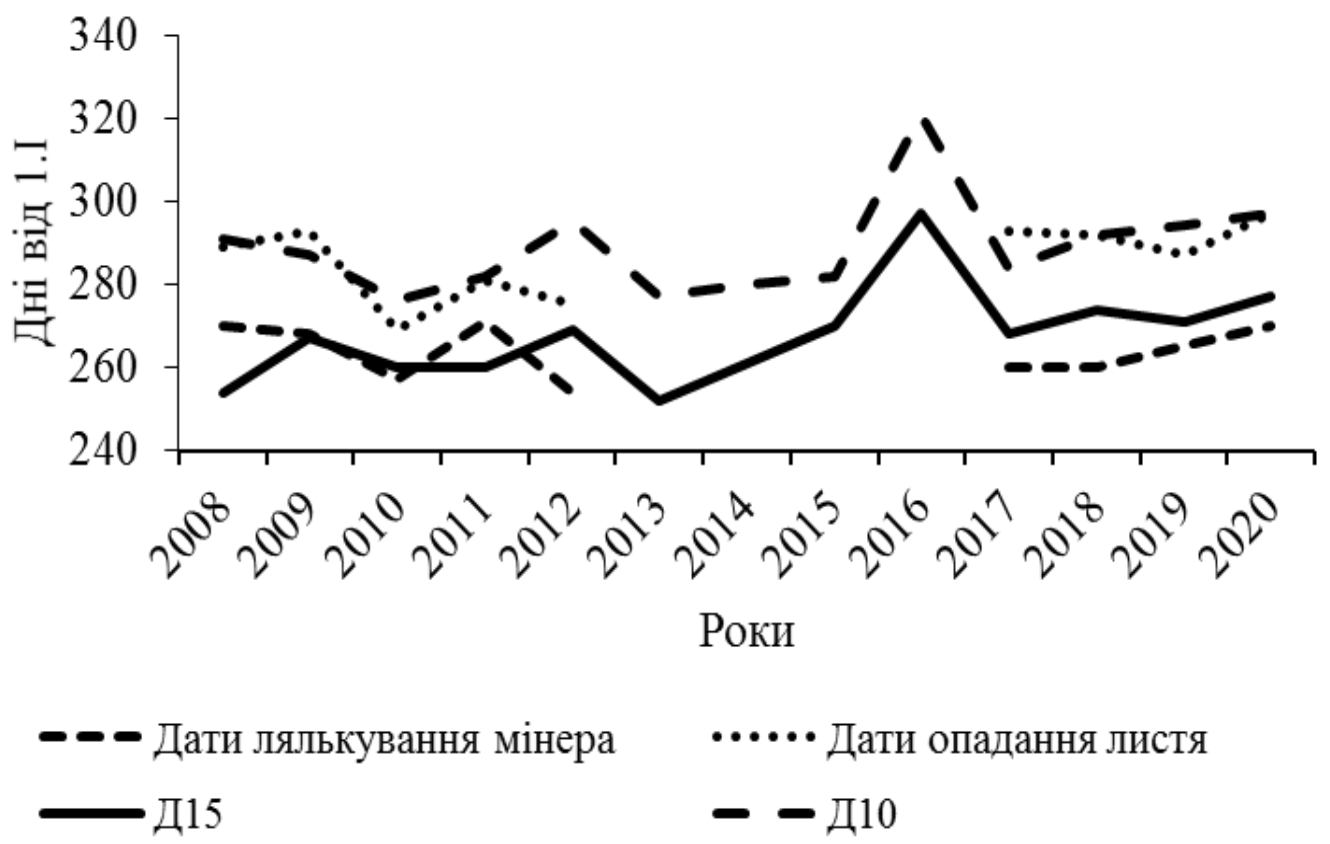

Puc. 5. Динаміка (2008-2020 pр.): дат стійкого переходу температури повітря восени через 15 i $10{ }^{\circ} \mathrm{C}$ (Д15 і Д10 відповідно) за даними метеостанції Харків; дат утворення лялечок каштанового мінера останнього покоління; лат опадання листя гіркокаштана у 2008-2012 pp. за опублікованими даними [13] та у 2017-2020 рр. за власними даними (дати виражені у кількості днів від 1 січня). 
Одержані дані свідчать, що каштановий мінер має сприятливі умови для розвитку від дат розпускання листя до дат початку опадання листя гіркокаштана.

У роки наших досліджень (2017-2020 pp.) початок опадання листя гіркокаштана в середньому зареєстрований на 12 днів пізніше, ніж за опублікованими даними [13]. Так само більш пізніми є дати стійкого переходу температури повітря вниз через 15 i $10{ }^{\circ} \mathrm{C}$ (табл. 2).

\section{Дати опадання листя гіркокаштана звичайного в зелених насадженнях Харкова та відповідні температурні показники у роки досліджень} (2017-2020 pp.) та у 2008-2012 pp.

\begin{tabular}{|c|c|c|c|c|c|c|c|}
\hline \multirow{3}{*}{ Роки } & \multicolumn{3}{|c|}{ Дати } & \multirow{3}{*}{$\mathrm{T}^{\circ} \mathrm{C} *$} & \multirow{2}{*}{\multicolumn{3}{|c|}{ Суми температур, ${ }^{\circ} \mathrm{C}$}} \\
\hline & \multirow{2}{*}{$\begin{array}{c}\text { опадання } \\
\text { листя }\end{array}$} & \multicolumn{2}{|c|}{$\begin{array}{c}\text { переходу } \\
\text { температури вниз } \\
\text { через }\end{array}$} & & & & \\
\hline & & $15^{\circ} \mathrm{C}$ & $10^{\circ} \mathrm{C}$ & & $\begin{array}{c}\text { додат- } \\
\text { них }\end{array}$ & $\begin{array}{c}\text { актив- } \\
\text { них }\end{array}$ & $\begin{array}{c}\text { ефектив- } \\
\text { них }\end{array}$ \\
\hline 2017 & $20 . X$ & 25.IX & 11.X & 12.0 & 3721.0 & 3321.3 & 1611.3 \\
\hline 2018 & 19.X & $1.10 .$. & 19.X & 14.7 & 3952.8 & 3827.1 & 1937.1 \\
\hline 2019 & $14 . X$ & 28.IX & $21 . \mathrm{X}$ & 16.0 & 3842.0 & 3546.2 & 1776.2 \\
\hline 2020 & $23 . \mathrm{X}$ & $3 . \mathrm{X}$ & $23 . \mathrm{X}$ & 14.0 & 3860.3 & 3507.2 & 1627.2 \\
\hline \multicolumn{8}{|l|}{ Середні } \\
\hline 2008-2012 & 7.X & 19.IX & 13.X & 14.8 & 3526.4 & 3287.4 & 1573.4 \\
\hline $2017-2020$ & 19.X & 30.IX & $19 . \mathrm{X}$ & 14.2 & 3844.0 & 3550.5 & 1738.0 \\
\hline Різниці & -12 & -11 & -6 & 0.6 & -317.6 & -263.1 & -164.5 \\
\hline
\end{tabular}

$* \mathrm{~T}^{\circ} \mathrm{C}$ - середня температура на дату опадання листя гіркокаштана

Суми додатних, активних i ефективних температур на дату початку опадання листя гіркокаштана у 20172020 рр. виявилися більшими, ніж у 20082012 рр. (табл. 2).

3 використанням даних, наведених у табл. 1 i 2, нами розраховано суми додатних, активних i ефективних температур за періоди вегетації гіркокаштана у 2008-2020 pp. (так звані доступні суми тепла [10]). Як було розраховано [13], для розвитку одного покоління каштанового мінера необхідно 979, 974 та $516{ }^{\circ} \mathrm{C}$ додатних, активних i ефективних температур відповідно. Згідно iз цим для визначення можливої кількості поколінь каштанового мінера суми тепла за вегетаційний період поділені на відповідні суми тепла, необхідного для розвитку одного покоління в умовах м. Харків.

У результаті таких обчислень встановлено (рис. 6), що за температурними умовами в насадженнях м. Харків каштановий мінер може розвиватися у трьох повних поколіннях. У 2008-2012 рр. потенційна кількість його поколінь, визначена 3 використанням сум додатних, активних i ефективних температур, становила 3.2, 3.1 і 2.9 відповідно, а у $2017-$ 2020 pp. - 3.4, 3.4 та 3.2 відповідно. Тобто частина популяції, яка спроможна розвиватися у додатковому поколінні, має тенденцію до збільшення. 


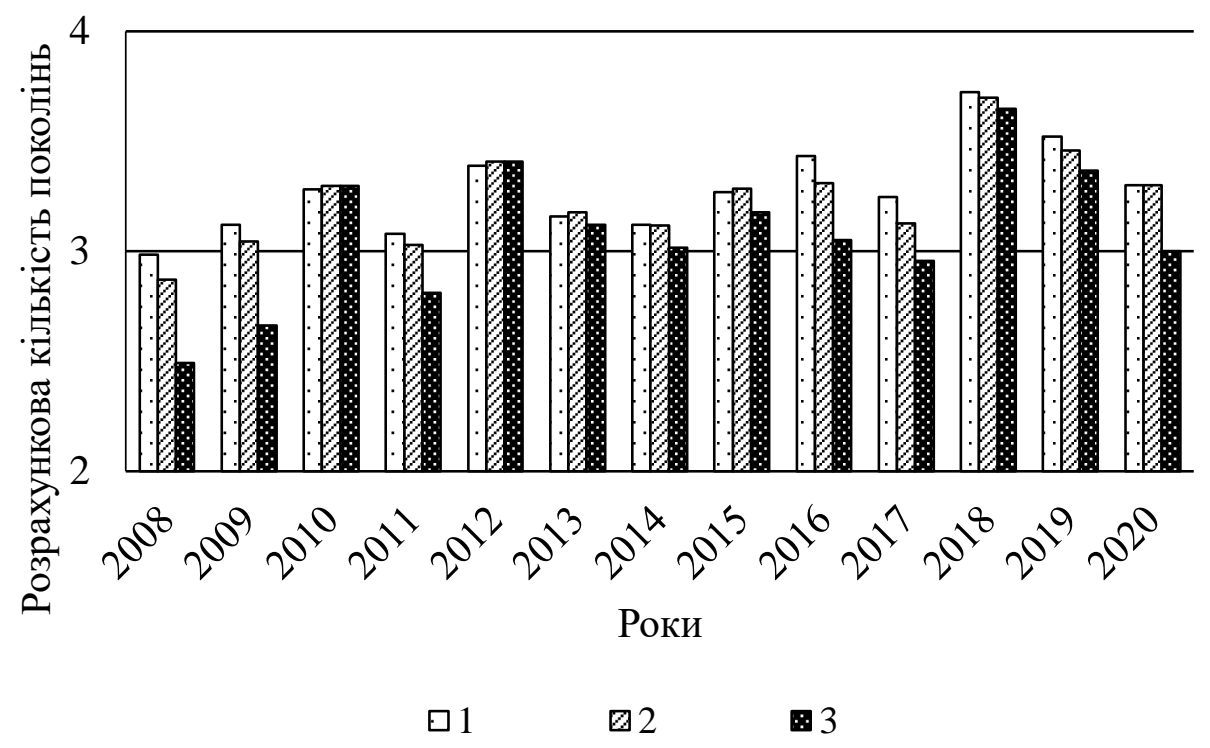

Puc. 6. Кількість поколінь каштанового мінера, розрахована за даними стосовно фактичних сум додатних (1), активних (2) і ефективних температур (3) і відповідних сум температур, необхідних для розвитку одного покоління

\section{ОБГОВОРЕННЯ}

Каштановий мінер виявлений на території Харківської області у 2006 р. [9], у Харкові - у 2007 [6, 11]. Вже в 2011 році цей вид поширився на всю територію України [3]. Під час дослідження поширення каштанового мінера у зелених насадженнях м. Харків у 2008-2011 pp. встановлено наявність достовірних відмінностей $\mathrm{y}$ щільності його мін у різних районах міста й y різних типах насаджень, а також тенденцію до збільшення чисельності та шкідливості цього виду [14].

Якщо у перший період інвазії щільність мін у вуличних посадках була значно меншою, ніж у парках, то у 20172020 pp. значення показника дуже близькі в усіх обстежених насадженнях, за винятком нещодавно висаджених молодих дерев (рис. 1). Можна припустити, що щільність мін каштанового мінера у насадженнях м. Харків практично досягла максимальної, за якої гусениці можуть успішно завершити живлення на листі гіркокаштана.

Дослідники в різних регіонах $[2,3,7$, 8] пов'язували меншу щільність популяції каштанового мінера у вуличних посадках із осіннім вилученням листя, в якому зимують лялечки [12]. Водночас цей захід впливає на щільність мін навесні, тоді як вже у наступному поколінні дерева заселяють особини, що мігрують із сусідніх насаджень [14].

Результати обліків поширення каштанового мінера на молодих деревах гіркокаштана (рис. 1) свідчать про високі темпи збільшення щільності мін, що $\epsilon$ характерним в умовах вселення виду у новий регіон [7, 17].

Каштановий мінер залежно від регіону та погодних умов року може мати від 2 до 5 поколінь на рік $[4,7,18]$. Під час досліджень у Харківській області встановлено наявність трьох поколінь та іноді появу особин четвертого покоління, які не мають змоги завершити розвитку [14]. Розрахунки О. М. Гаманової [3] свідчать про можливість розвитку трьох генерацій каштанового мінера у Поліссі, Прикарпатті й Закарпатті і лише двох генерацій (у деякі роки) у Сумській, Тернопільській і Хмельницькій областях.

Нами проаналізовано динаміку дат виявлення перших метеликів каштанового мінера навесні 2017-2020 pр., дат стійкого переходу температури повітря через $10 \mathrm{i}$ $15^{\circ} \mathrm{C}$, середньої температури повітря та суми додатних, активних i ефективних температур на дату виявлення перших 
метеликів каштанового мінера (табл. 1). Порівняння зазначених показників із аналогічними даними, одержаними у 20082012 рр., підтвердило висновки [12, 13], що виліт метеликів після зимівлі відбувається у проміжок часу між стійким переходом температури через 10 i $15{ }^{\circ} \mathrm{C}$ (рис. 2). Як відомо [18], лялечки каштанового мінера розвиваються впродовж 12-20 днів залежно від температури. Тобто якщо у зелених насадженнях м. Харків лялечки, які зимували, починали розвиватися після стійкого переходу температури через $10^{\circ} \mathrm{C}$ (у середньому за роками досліджень 16 квітня), то імаго у 2017-2020 рр. вилітали 23.04-06.05 (середня дата 30 квітня).

Порівняння температурних умов 2017-2020 pр. та 2008-2012 рр. (табл. 1) підтверджує відомості про зсув початку вегетаційного періоду на більш ранні дати [20].

Зареєстроване збільшення середньої температури на дату вильоту метеликів каштанового мінера може свідчити про швидше наростання температури навесні (табл. 1). Зменшення сум додатних, активних і ефективних температур на дату вильоту метеликів у 2017-2020 pp. у порівнянні з 2008-2012 pр. (табл. 1) можна пояснити тим, що на завершення розвитку лялечок після зимової діапаузи була витрачена менша сума температур. Водночас для вирішення цього питання потрібні окремі дослідження.

Під час аналізу сезонної динаміки щільності мін каштанового мінера в зелених насадженнях м. Харків визначено, що період १ii максимуму виражений найчіткіше у другій декаді липня (рис. 3). Про збіг літньої динаміки популяцій багатьох комах у різних регіонах повідомляють різні автори $[10,17,18]$. Варіювання

\section{ВИСНОВКИ}

1. У зелених насадженнях м. Харків щільність мін каштанового мінера у перші роки інвазії (2008-2011рр.) відрізнялася за біотопами й мала тенденцію до збільшення. У 2017-2020 рр. динаміка щільності мін $є$ подібною в усіх типах насаджень, за дат вильоту імаго навесні та сезонного розвитку весняного покоління може бути пов'язаним із відмінностями мікроклімату окремих ділянок, де опале листя 3 наявністю лялечок перебуває взимку, а також із варіюванням температури повітря під час розвитку лялечок. Вже у серпні у зв'язку з перекриванням окремих поколінь співвідношення гусениць, лялечок i екзувіїв у мінах майже не змінюється, а 3 початку вересня лялечки поступово йдуть у діапаузу (рис. 4). На зміни у темпах розвитку комах у другій половині літа впливає фотоперіод, що дає їм змогу до холодів опинитися в найбільш витривалій стадії розвитку $[10,17]$.

Аналіз показників перебігу температури повітря під час завершення вегетаційного періоду підтвердив, що останні лялечки каштанового мінера 3'являються на декілька днів раніше від дати стійкого переходу температури повітря вниз через $15^{\circ} \mathrm{C}$ та опадання листя, тобто у терміни, дуже близькі до дати стійкого переходу температури повітря через $10{ }^{\circ} \mathrm{C}$ (рис. 5). Усі зазначені явища у 2017-2020 pр. (табл. 2) зареєстровані пізніше, ніж у 2008-2012 рр., а суми додатних, активних i ефективних температур на дату початку опадання листя гіркокаштана у 2017-2020 pp. є більшими, ніж у 2008-2012 pp. [13].

Беручі до уваги одержані дані, розраховано можливу кількість поколінь каштанового мінера у зелених насадженнях м. Харків (рис. 6). Одержані дані свідчать, що загалом «гарантовано» ця комаха розвивається у трьох поколіннях на рік, але певна частка популяції, яка має тенденцію до збільшення, може розвиватися у додатковому поколінні.

винятком молодих дерев у перші роки після садіння.

2. Виліт метеликів каштанового мінера навесні відбувається у проміжок часу між стійким переходом температури через 10 i $15^{\circ}$ C. У 2017-2020 pр. вегетацій- 
ний період у м. Харків розпочався раніше, ніж у 2008-2012 рр., а середня температура на дату вильоту метеликів каштанового мінера збільшилася.

3. У динаміці щільності мін каштанового мінера в зелених насадженнях м. Харків визначено три періоди.

4. Останніх лялечок каштанового мінера виявляли у кронах на декілька днів раніше від дати стійкого переходу температури повітря вниз через $15^{\circ} \mathrm{C}$, а листя гіркокаштана опадало у дати, близькі

\section{Jimepamypa}

1. Anikin V. (2019). Present day bio-invasions in the Volga-Ural Region: from the South to the North or from the East to the West? Cameraria ohridella (Lepidoptera: Gracillariidae) in the Lower and Middle Volga. Zootaxa 4624(4), zootaxa-4624. DOI: $10.11646 /$ zootaxa.4624.4.9

2. Antyukhova O. V. (2008) Seasonal development of horse-chestnut leafminer in Transdniestria. Bull. of Plant Protection 4: 57-61.

3. Gamanova O. M. (2011) Horse-chestnut leafminer (Cameraria ohridella Deschka \& Dimic) and protection of horse-chestnut in the urban stands. Extended Abstract of Cand. Sci. (Agr.) Dissertation. Kyiv.

4. Gilbert M., Guichard S., Freise J., Gregoire J.C., Heitland W., Straw N., Tilbury C., Augustin S. (2005) Forecasting Cameraria ohridella invasion dynamics in recently invaded countries: from validation to prediction. Journal of Applied Ecology 42: 805-813 https://doi.org/10.1111/j.1365-2664.2005.01074.X

5. Gninenko Y. I., Muhamadiev N. S., Ashikbaev N. Z. (2017) Cameraria ohridella: the first record in Central Asia. Russian journal of biological invasions 8(1): 10-13.

6. Guglya Yu. A., Zinenko A. I. (2008) New data on the dispersal of the chestnut mining moth, Cameraria ohridella (Lepidoptera: Gracillariidae) in the territory of Ukraine. Bulletin of Zoology 42(3): 220.

7. Kirichenko N., Augustin S., Kenis M. (2019). Invasive leafminers on woody plants: a global review of pathways, impact, and management. Journal of Pest Science 92(1): 93-106. https://doi.org/10.1007/s10340018-1009-6

8. Lesovoy N., Fedorenko V., Vigera S., Chumak P., Kliuchevych M., Strygun O., \& Vagaliuk L. (2020) Biological, Trophological, Ecological and Control Features of Horse-Chestnut Leaf Miner (Cameraria ohridella Deschka \& Dimic). Ukrainian Journal of Ecology 10(3): 24-27. doi: 10.15421/2020_128

9. Maksimova Yu. P., Boychuk Yu. D., Mukhina O. Yu. (2009) Faunistic complex of mining insects in Kharkov. Proceedings of the 2nd International. conf. "Current problems of biology, ecology and chemistry" (1-3 October 2009, Zaporizhzhya). Zaporizhzhya: ZNU, pp. 54-55. до стійкого переходу температури повітря вниз через $10{ }^{\circ} \mathrm{C}$. Зазначені явища у 20172020 рр. зареєстровані пізніше, ніж у 20082012 pp.

5. У насадженнях м. Харків каштановий мінер «гарантовано» розвивається у трьох поколіннях на рік. Водночас зважаючи на зміни дат початку й завершення сезонного розвитку цього виду, можна очікувати, що певна частка популяції може мати додаткове (четверте) покоління.

10. Meshkova V. L. (2009) Seasonal development of foliage browsing insects. Kharkiv: Novoe slovo.

11. Meshkova V. L., Mikulina I. M. (2008) Optimizing of assessment of Cameraria ohridella Deschka and Dimic, 1986 (Lepidoptera: Gracillariidae). Forestry \& Forest Melioration 114: 182-186.

12. Meshkova V. L., Mikulina I. M. (2012) Seasonal development of invasion moth-miners in green stands of Kharkov. Ecological and economic consequences of invasion of dendrophilous insects. Proceedings of All-Russian conference with international participation. (Sept. 25-27, 2012, Krasnoyarsk, Russia). Krasnoyarsk: IL SO RAN, pp.168-171.

13. Meshkova V. L., Mikulina I. M. (2013) Seasonal development of horse-chestnut leafminer, Cameraria ohridella Deschka et Dimić, 1986 (Lepidoptera: Gracillariidae) in the green stands of Kharkov. The Kharkov Entomol. Soc. Gaz. 21(2): 29-37.

14. Mikulina I. M. (2012) Biological background of broadleaved trees protection from adventive mothsminers in green stands of Kharkov region. Extended Abstract of Cand. Sci. (Agr.) Dissertation, Kharkiv.

15. Paterska M., Bandurska H., Wysłouch J., Molińska-Glura M., Moliński K. (2017) Chemical composition of horse-chestnut (Aesculus) leaves and their susceptibility to chestnut leaf miner Cameraria ohridella Deschka \& Dimić. Acta physiologiae plantarum 39(4): 105. DOI 10.1007/s11738-017-2404-y

16. Roginsky A., Buga S. (2020) The leaf surface damage of horse chestnut caused by the horse chestnut leaf-miner larvae in Belarus after the completion of the invader's expansion. Lesia Ukrainka Eastern European National University Scientific Bulletin Series: Biological Sciences 1 (389): $51-59$. DOI https://doi.org/10.29038/2617-4723-2020-1-389-51-59

17. Saulich A. Kh. (1999) Seasonal development of insects and the possibility of their dispersal. St. Petersburg: SPb University.

18. Sefrova H. (2001). Control possibility and additional information on the horse-chestnut leafminer Cameraria ohridella Deschka\&Dimic (Lepidoptera, Gracillariidae). Acta Universitatis Agriculturae et Silviculturae Mendelianae Brunensis 49 (5): 121-127. 
19. Sefrova H., Lastuvka Z. (2001) Dispersal of the horse-chestnut leafminer Cameraria ohridella in Europe: its course, ways and causes. Entomol. Zeit. Stuttgart 111: 195-198.
20. Shvydenko A. Z., Buksha I. F., Krakovskaya S. V. (2018) Vulnerability of forests of Ukraine to climate change. Kyiv: Nika-Center.

21. Wardlaw A. C. (2000). Practical statistics (pp. 45-63). John Wiley \& Sons Ltd, West Sussex, England.

\title{
UDC $595.783: 632.78$
}

\section{FEATURES OF DYNAMICS OF MINE DENSITY AND PHENOLOGY OF THE HORSE-CHESTNUT LEAF MINER (CAMERARIA OHRIDELLA DESCHKA \& DIMIC, 1986) IN PLANTATIONS OF KHARKIV}

\author{
I. M. Shvydenko, Ye. S.Kardash, M. S.Kolienkina
}

The aim of the research is to assess the long-term and seasonal dynamics of the mine density and phenology of the horse-chestnut miner Cameraria ohridella Deschka \& Dimic, 1986 (Lepidoptera, Gracillariidae) in different types of green plantations in Kharkiv in 2017-2020 and to compare these results with the data of 2008-2011 against the background of the corresponding parameters of air temperature course. It was found that in the first years of the invasion (2008-2011) in the green plantations of Kharkiv, the density of mines of the horse-chestnut leaf miner tended to increase, and in the parks, it was much higher than in the street plantations. In 2017-2020, the density of the moth is close in all types of plantations, except for young trees in the first years after planting. The swarming of Cameraria ohridella moths in the spring occurs after a stable increase of temperature above $10^{\circ} \mathrm{C}$, but before its increase above $15^{\circ} \mathrm{C}$. Compared to 2008-2011, the growing season in 2017-2020 began earlier, the average temperature at the date of swarming of the horsechestnut leaf miner increased, and the sums of positive, active, and effective temperatures decreased. During the growing season, three generations of Cameraria ohridella develop in the green plantations of Kharkiv, and the period of the highest density of mines in the second decade of July is most evident. The density of leaf mines in certain dates of development of the spring generation depends on the microclimate of the locations of pupae in fallen leaves, the course of temperature during the moths' laying eggs period, and the development of larvae and pupae. The density of mines in the second half of the summer is influenced by the overlap of the development of different generations and the gradual starting of diapause of the part of the population. The last pupae of the horse-chestnut leaf miner were found in the crowns a few days before the date of stable decrease of air temperature down below $15^{\circ} \mathrm{C}$, and the leaves fell at time very close to the date of stable decrease of air temperature below $10^{\circ} \mathrm{C}$. These phenomena in 2017-2020 were registered later than in 2008-2012, and the sums of positive, active and effective temperatures at the date of the beginning of the fall of horse-chestnut leaves in 2017-2020 are higher than in 2008-2012. It is estimated that in the green plantations of Kharkiv, the horse-chestnut leaf miner is 'guaranteed' to develop in three generations per year. At the same time, given the changes in the start and end dates of the seasonal development of the horse-chestnut leaf miner, it can be expected that a certain proportion of the population will develop in the additional generation.

Key words: Cameraria ohridella, mine density, seasonal development, generations, air temperature, a sum of temperatures.

Стаття надійшла 22. 10. 2020 р. Рекомендована до друку на засіданні редакційної колегії після рецензування 